Bull. Egypt. Soc. Physiol. Sci. Vol. (41) Issue (1), 110- 120

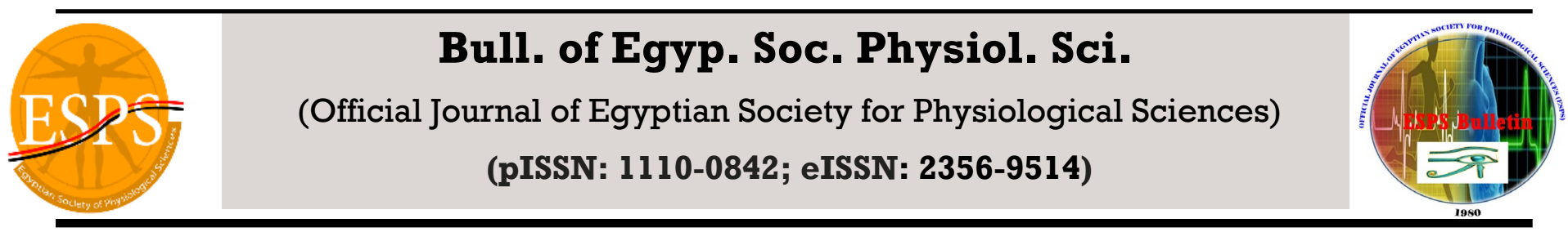

\title{
Interferon regulatory factor (5) Gene Variants (rs2004640) as Genetic Risk Factors for Systemic Lupus Erythematosus but not Lupus Nephritis in Egyptian adults
}

\author{
${ }^{*}$ Sally M. El-Hefnawy ${ }^{1}$ Rasha G. Mostafa ${ }^{2}$, Heba E. Kasem ${ }^{3}$, Enas S. Zahran ${ }^{3}$ and Sherein S. \\ ELnaidany ${ }^{1}$ \\ ${ }^{1}$ Medical Biochemistry \& Molecular Biology department, Menoufia Faculty of Medicine, Egypt \\ ${ }^{2}$ Microbiology \& Immunology Department, Menoufia Faculty of Medicine, Egypt \\ ${ }^{3}$ Internal Medicine Department, Menoufia Faculty of Medicine, Egypt
}

Submit Date: May 4, 2020

Accept Date: June 15, 2020

Available Online: Jan 1, 2021

\section{Keywords}

- IRF5

- Gene polymorphism

- SLE

\begin{abstract}
Systemic lupus erythematosus (SLE) is an autoimmune disease with complex etiology. Genetic aberrations disrupting the immune regulatory mechanisms may initiate autoimmune disease development. Recent studies have proved that the interferon regulatory factor 5 (IRF5) gene is an important risk factor for SLE. We aimed to investigate the association of the rs2004640 polymorphism within the IRF5 gene with SLE and lupus Nephritis and SLE activity in a sample of adult Egyptian population. 199 individuals were classified into: group I: included 118 patients who were further subdivided into 57 patients with and 61 patients without lupus nephritis respectively and group II: 81 healthy subjects as controls. Genotyping of the SNP rs2004640 at IRF5 gene was analyzed via allele discrimination assay using Real-Time PCR. TT genotype was the most abundant among SLE patients $(\mathrm{p}=0.001)$, but $\mathrm{GG}$ genotype was the most abundant in controls $(\mathrm{p}=0.001)$ while, genotype frequency showed no significant statistical difference between lupus patients with and without nephritis ( $\mathrm{p}=0.2,0.1$ respectively). The multivariate analysis of prediction of SLE activity [assessed by systemic lupus erythematosus disease activity index (SLEDAI) scoring] showed that the protein/creatinine ratio $(95 \% \mathrm{CI}, 0.001$ to 0.002$)$ and antidsDNA ( $95 \%$ CI, 0.005 to 0.1 ) were independent factors of SLE activity ( $\mathrm{OR}=0.001$ and 0.008 respectively). IRF5 gene polymorphism (rs2004640) might be candidate risk factor for developing SLE but not risk factor for lupus nephritis or the disease activity in a sample of adult Egyptian population.
\end{abstract}

Corresponding author: Sally Mohammed El-Hefnway, Address: Shebein Al-Kom-Menoufia- Egypt Tel: +201009896870 , Fax: +20482181009, Email: doctor_sally@rocketmail.com, Medical Biochemistry \& Molecular Biology department, Menoufia Faculty of Medicine, Egypt 


\section{INTRODUCTION}

Systemic lupus erythematosus (SLE) is an autoimmune disease that displays marked clinical heterogeneousness with strong genetic linkages and environmental factors [1]. SLE affects several parts of the body such as skin, lungs, joints, kidneys, heart, nervous system, and hematopoietic tissue [2]. SLE can differ widely in severity, both at onset and course; some patients may present with mild symptoms and no serious organ affection, however others may present with severe symptoms with marked organ involvement [3]. Lupus results from absence of tolerance with insider's antigens and production of antibodies attacking the cell nucleus [4]. About $30 \%$ of all patients with SLE firstly present with nephritis and half of cases have nephritis during the first 10 years. This condition increases mortality and morbidity rates among patients, the risk of chronic kidney disease with the need for renal replacement therapy in about one quarter of cases [5]. Interferon regulatory factor 5 (IRF5) is a transcription factor inducing the transcription of pro-inflammatory cytokines such as IFN- $\alpha$, TNF$\alpha$, IL-12 and IL-6 through activation of nuclear factor- $\kappa \mathrm{B}(\mathrm{NF}-\kappa \mathrm{B})$ pathway [5]. IRF5 gene present on the long arm of chromosome 7 at locus no. 32, and its expression is linked to atopic diseases [6]. IRF5 gene polymorphisms have been shown to be a genetic risk factor for autoimmune diseases such as SLE, inflammatory bowel disease, scleroderma, Sjögren's syndrome and rheumatoid arthritis [7]. The rs2004640 T allele creates a 5' donor splice site in an alternate exon 1 of IRF5, allowing expression of several unique IRF5 isoforms. We also identify an independent cis-acting variant associated with elevated expression of IRF5 and linked to the exon 1B splice site. Haplotypes carrying the variant associated with elevated expression and lacking the exon 1B donor site do not confer risk of SLE. Thus, a common IRF5 haplotype driving elevated expression of multiple unique isoforms of IRF5 is an important genetic risk factor for SLE, establishing a causal role for type I IFN pathway genes in human autoimmunity [8].

The aim of this study was to examine the association between IRF5 gene polymorphism (rs2004640) with systemic lupus erythematosus \& lupus Nephritis and to predict SLE activity (assessed by SLEDAI score) in a sample of Egyptian population.

\section{2 | METHODS}

\section{1 | SUBJECTS}

This study was carried out by cooperation between Medical Biochemistry \& Molecular Biology, Nephrology and Rheumatology units of Internal Medicine Departments, Faculty of Medicine in the period from April 2017 to July 2019. It was carried out on 199 individuals grouped into: group I: included 118 SLE patients who were further subdivided into 57 patients with lupus nephritis and 61 patients without lupus nephritis and group II: included 81 age and sex matched healthy subjects as controls. Pathological grading of the lupus nephritis is classified by International Society of Nephrology (ISN) and the Renal Pathology Society (RPS) 2003 criteria [9]. All lupus nephritis cases fulfilled the revised American College of Rheumatology criteria for SLE [10], and the disease activity in SLE patients was evaluated and graded by systemic lupus erythematosus disease activity index (SLEDAI) 
[11]. Patients with hepatic, renal (other than SLE) or malignant diseases, drug-induced lupus cases, SLE patients with pregnancy and SLE patients with other connective tissue disorders were excluded from the study.

\subsection{ETHICS APPROVAL AND CONSENT TO PARTICIPATE}

Before blood sampling, written consent was taken from all participants (accepted by "the Local Ethics \& Human Rights committee in Research at Faculty of Medicine, Menoufia University") in accordance with Helsinki declaration of 1974 (revised in 2000).

\subsection{SAMPLING AND PRIMARY TEST}

Both of patients and controls were exposed to history taking, clinical examination. Relevant clinical \& medical data were collected with particular stress on onset of SLE, duration of disease $\&$ family history of autoimmune disease. Laboratory investigations were done in the form of: $\mathrm{CBC}$, ESR, kidney \& liver function tests, antinuclear Antibody (ANA) \& anti double stranded deoxyribonucleic acid (Anti-ds DNA). Genetic analysis of Interferon regulatory factor 5 (IRF5) rs2004640 polymorphism was done by real time PCR technique.

Ten mLs of venous blood were withdrawn from all subjects as follows: $2 \mathrm{mLs}$ were collected in EDTA tube for molecular testing of IRF5 rs2004640. $2 \mathrm{mLs}$ were collected in another EDTA tube for $\mathrm{CBC}$. The remaining $6 \mathrm{mLs}$ were transferred to plain tube to separate serum for assessment of urea, creatinine by colorimetric methods and autoantibody profile Antinuclear Antibody \& Anti-ds DNA.

The serum urea levels were measured via Mod Berthelot enzymatic colorimetric method using
Diamond Diagnostics Kit, Germany, serum and urinary creatinine were measured by fixed rate kinetic chemical method, using Diamond Diagnostics Kit, Germany. Anti-dsDNA was assessed by ELISA technique using Eagle Biosciences kit, USA. ANA were detected using Human ANA Cortez Diagnostic Screen ELISA kit, USA. Urinary protein was measured using the turbidimetric method and the Auto Analyzer Hitachi Modular DPP system (Roche). The results were expressed as grams of protein / $\mathrm{mg}$ of creatinine to determine the urinary protein/creatinine ratio. estimated glomerular filtration rate (eGFR) was calculated by the MDRD equation: [GFR $=186 \times($ serum $(\mathrm{Cr})-1.154$ $\times($ Age $)-0.203 \times(0.742$ if female $) \times(1.210$ if African American)] [12].

\subsection{IRF5 rs2004640 genotyping}

DNA was extracted from EDTA blood sample using GeneJET Whole Blood DNA extraction Kit (Thermo Scientific, USA). IRF5 gene was analyzed via the TaqMan allele Discrimination method, determining variations of single nucleotide sequence. Using two primer/probe sets in every reaction permit genotyping of the two probable variants at SNP in a target template sequence (Readymade assay from Thermo Scientific Fisher) [13], the assay details were as following: Catalog number: $\underline{4351379}$,Context Probe Sequence [VIC/FAM] GCTGCGCCTGGAAAGCGAGCTCGGG [G/T] GGGTGCCTACAGCAGGGTGCGCCCG and forward primer sequence: 5'CACCGCAGACAGGTGGG-3', reverse primer sequence: 5'-GGGAGGCGCTTTGGAAGT-3. Using genotyping specific Master Mix (MM), primers and probes were applied; the genotyping 
reaction was done by addition $10 \mu \mathrm{l}$ of $\mathrm{MM}, 1.25$ $\mu \mathrm{l}$ of the genotyping ready-made assay and $3.75 \mu \mathrm{l}$ of nuclease free water. For each reaction, $5 \mu \mathrm{l}$ of extracted DNA or $5 \mu \mathrm{l}$ of nuclease free water for the negative control reaction were applied. The cycling program was as follows: Denaturation firstly was done at $95^{\circ} \mathrm{C}$ for 10 minutes, then 50 cycles of denaturation at $94^{\circ} \mathrm{C}$ for 30 seconds, annealing at $50^{\circ} \mathrm{C}$ for 60 seconds and then extension at $72^{\circ} \mathrm{C}$ for 2 minutes and the last extension at $72^{\circ} \mathrm{C}$ for 1 minute. Data analysis was done by 7500 Real-Time PCR System, software version 2.0.1 [14].

\section{3 | STATISTICAL ANALYSIS}

All data were statistically analyzed using SPSS 23.0 for Windows (IBM Corp, Armonk, NY, USA) and MedCalc 13 for windows (MedCalc Software BVBA, Ostend, Belgium). Quantitative data were expressed as mean $\pm \mathrm{SD}$. It was analyzed by applying t-test for comparison between two groups and ANOVA for comparison between more than two groups of normally distributed variables. For the qualitative data, it was expressed in the form of number and percentage and then it was analyzed by applying $\chi^{2}$ for comparison between two or more independent qualitative variables normally distributed. Calculation of allelic frequency for both patients and controls was performed. The $\chi^{2-}$ test was used to compare allele frequency of the IRF5 gene polymorphism between SLE patients and controls. Kruskal-Wallis Test is used for comparison between more than 2 groups which are not normally distributed. Odds ratio and $95 \%$ confidence interval (CI) were measured to compare SLE risk around genotypes and alleles. Logistic regression analysis was used for prediction of proteinuria. $\mathrm{P}<0.05$ was considered as statistically significant.

\section{RESULTS}

Our study involved 199 individuals divided into two groups, 118 systemic lupus patients , (8 male \& 110 female) and 81 controls, (8 male \& 73 female), there were no significant statistical difference between patients and controls as regards age $(p=0.1)$ and gender (Figure 3$) \quad(p=0.2)$ that indicates group matching (Table 1). There was a significant statistical difference between two studied groups as regards genotype of IRF5 rs2004640, with high frequency of TT genotype among SLE patients and increase risk by 2.9 folds, while GG genotype was the most abundant in controls $(\mathrm{p}=0.001)$. Allelic distribution showed that $\mathrm{T}$ allele was the dominant in group I with elevated risk of lupus by 2.6 times $(<0.001)$, The IRF5 rs2004640 polymorphism could increase SLE risk in both dominant and recessive models (Table 2). IRF5 rs2004640 polymorphisms were consistent to the Hardy-Weinberg equilibrium in the control and SLE groups (table 3). In this study, the TT genotype is significantly associated with the clinical presentation in form of CNS lupus ( $p=$ $0.02)$, laboratory data in form of anti-dsDNA titre, protein/creatinine ratio $(\mathrm{p}=0.006,0.03)$ and with SLE Disease Activity Index (SLEDAI) (11.9 \pm 8.04, $\mathrm{p}=0.002$ ) (table 5). The genotype frequency of IRF5 rs2004640 and its alleles distribution showed no significant statistical difference between lupus patients with and without nephritis $(p=0.2, \quad 0.1 \quad$ respectively) (Table 4$) . T$ The multivariate analysis of prediction of SLE activity (assessed by SLEDAI scoring) showed that protein/creatinine ratio $(95 \% \mathrm{CI}, 0.001$ to 0.002$)$ and anti-dsDNA (95\% CI, 0.005 to 0.1$)$ were 
independent factors of SLE activity, while (TT+GT) genotype of IRF5 rs2004640 showed non-significant association with prediction of activity of SLE (95\% CI, 0.2 to 1.08$)(\mathrm{P}$ value $=$
0.07) (Table 6) . The resulting allelic discrimination \& amplification plots were shown in figure $1 \& 2$ respectively.

Table 1: Demographic, clinical and laboratory data of the SLE patients and controls

\begin{tabular}{|l|l|l|l|l|}
\hline & \multicolumn{1}{|c|}{$\begin{array}{c}\text { Group I } \\
\text { SLE patients } \\
\text { (N=118) }\end{array}$} & \multicolumn{1}{|c|}{$\begin{array}{c}\text { Group II } \\
\text { Controls (N=81) }\end{array}$} & Test & P value \\
\hline Age (years) & $29.1 \pm 8.3$ & $30.7 \pm 8.4$ & 1.3 & 0.1 \\
\hline $\begin{array}{l}\text { Gender } \\
\begin{array}{l}\text { Female N (\%) } \\
\text { Male N (\%) }\end{array}\end{array}$ & $\begin{array}{l}110(93.2 \%) \\
8(6.8 \%)\end{array}$ & $\begin{array}{l}73(90.1 \%) \\
8(9.9 \%)\end{array}$ & 0.6 & 0.2 \\
\hline $\begin{array}{l}\text { Systolic Blood pressure } \\
\text { (mmHg) }\end{array}$ & $123.5 \pm 16.3$ & $108.02 \pm 11.6$ & 7.3 & $<0.001$ \\
\hline $\begin{array}{l}\text { Diastolic Blood pressure } \\
\text { (mmHg) }\end{array}$ & $79.6 \pm 10.8$ & $70 \pm 3.6$ & 7.1 & $<0.001$ \\
\hline
\end{tabular}

Table 2: Genotypes Frequency and Allelic Distribution of IRF5 rs2004640 in SLE patients and controls

\begin{tabular}{|c|c|c|c|c|}
\hline & $\begin{array}{l}\text { SLE patients } \\
(\mathrm{N}=118)\end{array}$ & $\begin{array}{l}\text { Control } \\
(\mathrm{N}=81)\end{array}$ & OR $(95 \%$ CI) & P value \\
\hline \multicolumn{5}{|l|}{ Genotype } \\
\hline TT* & $26(22.03 \%)$ & $7(8.6 \%)$ & $2.9(1.2$ to 7.2$)$ & \multirow[t]{3}{*}{0.001} \\
\hline GT & $44(37.2 \%)$ & $19(23.5 \%)$ & $0.5(0.2$ to 0.9$)$ & \\
\hline GG & $48(40.6 \%)$ & $55(67.9 \%)$ & & \\
\hline \multicolumn{5}{|l|}{ Allele } \\
\hline$T^{*}$ & $96(40.6 \%)$ & $33(20.3 \%)$ & $2.6(1.6$ to 4.2$)$ & \multirow[t]{2}{*}{$<0.001$} \\
\hline $\mathbf{G}$ & $140(59.4 \%)$ & $129(79.7 \%)$ & & \\
\hline Dominant & & & $3.08(1.7$ to 5.5$)$ & $<0.001$ \\
\hline Recessive & & & $2.9(1.2$ to 7.2$)$ & 0.01 \\
\hline Over-dominant & & & 1.9 (1.02 to 3.6) & 0.04 \\
\hline
\end{tabular}

CI : confidence interval, OR: odds ratio $* \mathrm{P}<0.05$ : significant

Table 3: Distribution of observed genotype frequencies and their consistent with Hardy-Weinberg

\begin{tabular}{|c|c|c|c|c|}
\hline $\begin{array}{l}\text { IRF5 gene } \\
\text { polymorphism }\end{array}$ & Observed & Expected & $\mathbf{c}^{2}$ & P value \\
\hline \multicolumn{5}{|l|}{ SLE patients $(\mathrm{n}=118)$} \\
\hline GG & 48 & 41 & \multirow[b]{3}{*}{3.01} & \multirow[b]{3}{*}{0.2} \\
\hline GT & 44 & 57 & & \\
\hline TT & 26 & 20 & & \\
\hline \multicolumn{5}{|l|}{ Control $(\mathrm{n}=81)$} \\
\hline GG & 55 & 51 & \multirow{3}{*}{2.1} & \multirow{3}{*}{0.3} \\
\hline GT & 19 & 26 & & \\
\hline TT & 7 & 4 & & \\
\hline
\end{tabular}

If $P<0.05$ - not consistent with HWE. 
Table 4: Genotypes Frequency and Allelic Distribution of IRF5 rs2004640 in SLE patients with and without nephritis

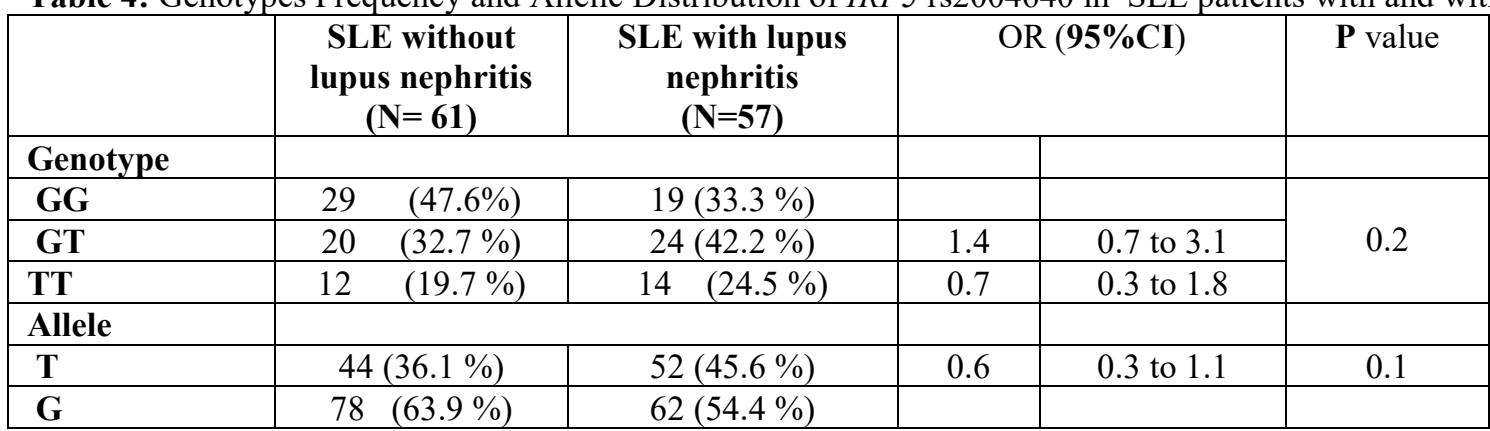

CI : confidence interval, OR: odds ratio

Table 5: IRF5 rs2004640 genotyping and clinical and laboratory data of SLE patient

\begin{tabular}{|c|c|c|c|c|c|}
\hline 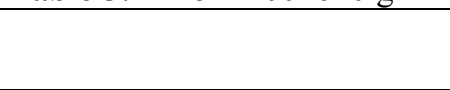 & $\begin{array}{c}\text { GG } \\
(\mathrm{N}=48)\end{array}$ & $\begin{array}{c}\text { GT } \\
(\mathrm{N}=44)\end{array}$ & $\begin{array}{c}\text { TT } \\
(\mathrm{N}=26)\end{array}$ & test & P value \\
\hline Systolic pressure mmHg & $120.2 \pm 14.1$ & $125.3 \pm 15.9$ & $126.5 \pm 19.9$ & 1.7 & 0.1 \\
\hline Diastolic pressure mmHg & $77.4 \pm 10.7$ & $81.8 \pm 10.8$ & $80 \pm 10.9$ & 1.9 & 0.1 \\
\hline Discoid lupus \% & $4(8.3 \%)$ & $5(11.3 \%)$ & $1(3.8 \%)$ & 1.1 & 0.5 \\
\hline Alopecia \% & $11(22.9 \%)$ & $25(56.8 \%)$ & $11(42.3 \%)$ & 11.9 & 0.004 \\
\hline Serositis \% & $10(20.8 \%)$ & $13(29.5 \%)$ & $14(53.8 \%)$ & 8.6 & 0.01 \\
\hline Arthritis \% & $13(27.1 \%)$ & $31(70.4 \%)$ & $26(100 \%)$ & 1.4 & 0.4 \\
\hline CNS (N\%) & $3(6.2 \%)$ & $1(2.1 \%)$ & $7(26.9 \%)$ & 12.6 & 0.02 \\
\hline Anti dsDNA titre & $244.7 \pm 320.1$ & $173.8 \pm 142.1$ & $406.5 \pm 397.5$ & 5.3 & 0.006 \\
\hline Hb g/dl & $9.7 \pm 0.9$ & $9.8 \pm 0.8$ & $9.9 \pm 0.8$ & 0.6 & 0.5 \\
\hline WBCs $\times 10^{9}$ & $5340 \pm 1668$ & $4809 \pm 1457$ & $3869 \pm 1904$ & 6.7 & 0.002 \\
\hline Platelet $\times 10^{9}$ & $234.1 \pm 108.6$ & $188.1 \pm 75.1$ & $193.8 \pm 131.4$ & 2.5 & 0.08 \\
\hline Protein/creatinine ratio g/mg & $1.6 \pm 2.2$ & $2.2 \pm 2.5$ & $3.4 \pm 3.7$ & 3.5 & $\mathbf{0 . 0 3}$ \\
\hline Serum creatinine $\mathrm{mg} / \mathrm{dl}$ & $0.7 \pm 0.1$ & $0.7 \pm 0.2$ & $0.7 \pm 0.1$ & 0.04 & 0.9 \\
\hline eGFR $\mathrm{ml} / \mathrm{min}\left(1.73 \mathrm{~m}^{2}\right)$ & $94.3 \pm 23.8$ & $89.7 \pm 23.5$ & $89.1 \pm 36.5$ & 0.4 & 0.6 \\
\hline $\begin{array}{l}\text { Class( II+V) \% } \\
\text { Class (IV +III) \% }\end{array}$ & $\begin{array}{c}1(5.2 \%) \\
18(94.8 \%)\end{array}$ & $\begin{array}{c}4(16.6 \%) \\
20(83.4 \%)\end{array}$ & $\begin{array}{l}3(21.4 \%) \\
11(78.6 \%)\end{array}$ & 1.9 & 0.3 \\
\hline SLEDAI & $5.8 \pm 4.6$ & $5.1 \pm 4.5$ & $11.9 \pm 8.04$ & 13.6 & 0.002 \\
\hline $\begin{array}{l}\text { No } \\
\text { Mild } \\
\text { moderate } \\
\text { Severe } \\
\end{array}$ & $\begin{array}{c}15(31.3 \%) \\
21(43.7 \%) \\
11(22.9 \%) \\
1(2.1 \%) \\
\end{array}$ & $\begin{array}{l}14(31.8 \%) \\
17(38.7 \%) \\
11(25 \%) \\
2(4.5 \%) \\
\end{array}$ & $\begin{array}{c}1(3.9 \%) \\
9(34.6 \%) \\
9(34.6 \%) \\
7(26.9 \%) \\
\end{array}$ & 20.9 & 0.002 \\
\hline
\end{tabular}

CNS: central nervous system, eGFR: estimated glomerular filtration rate, SLEDAI:systemic lupus erythematosus disease activity index

Table 6: Univariate and Multivariate regression analysis for prediction of SLE activity (SLEDAI score)

\begin{tabular}{|c|c|c|c|c|c|c|}
\hline & HR & $\begin{array}{l}\text { (univariate } \\
\text { analysis CI } 95 \% \text { ) }\end{array}$ & $P$ value & HR & $\begin{array}{l}\text { (Multivariate } \\
\text { analysis CI } 95 \% \text { ) }\end{array}$ & $\begin{array}{l}\mathbf{P} \\
\text { value }\end{array}$ \\
\hline Age (years) & -0.006 & $(-0.1$ to 0.1$)$ & 0.9 & & & \\
\hline Age of onset & 0.05 & $(-0.06$ to 0.1$)$ & 0.3 & & & \\
\hline Duration of disease & 0.8 & $(0.4$ to 1.3$)$ & 0.0001 & 1.1 & $(0.2$ to 2.2$)$ & 0.04 \\
\hline Sex (male) & 1.3 & (0.8 to 2.4$)$ & 0.07 & & & \\
\hline $\begin{array}{l}\text { Protein/creatinine } \\
\text { ratio }(\mathrm{g} / \mathrm{mg})\end{array}$ & 0.001 & (0.001 to 0.002$)$ & $<0.001$ & 0.001 & $(0.001$ to 0.002$)$ & $<0.001$ \\
\hline (TT+TG) vs (GG) & 0.7 & $(0.2$ to 1.08$)$ & 0.07 & & & \\
\hline Anti dsDNA titre & 0.01 & $(0.006$ to 0.013$)$ & 0.001 & 0.008 & $(0.005$ to 0.1$)$ & $<0.001$ \\
\hline Class (III+IV) & 0.6 & $(0.4$ to 1.9$)$ & 0.9 & & & \\
\hline
\end{tabular}

CI : confidence interval, HR: hazard ratio 


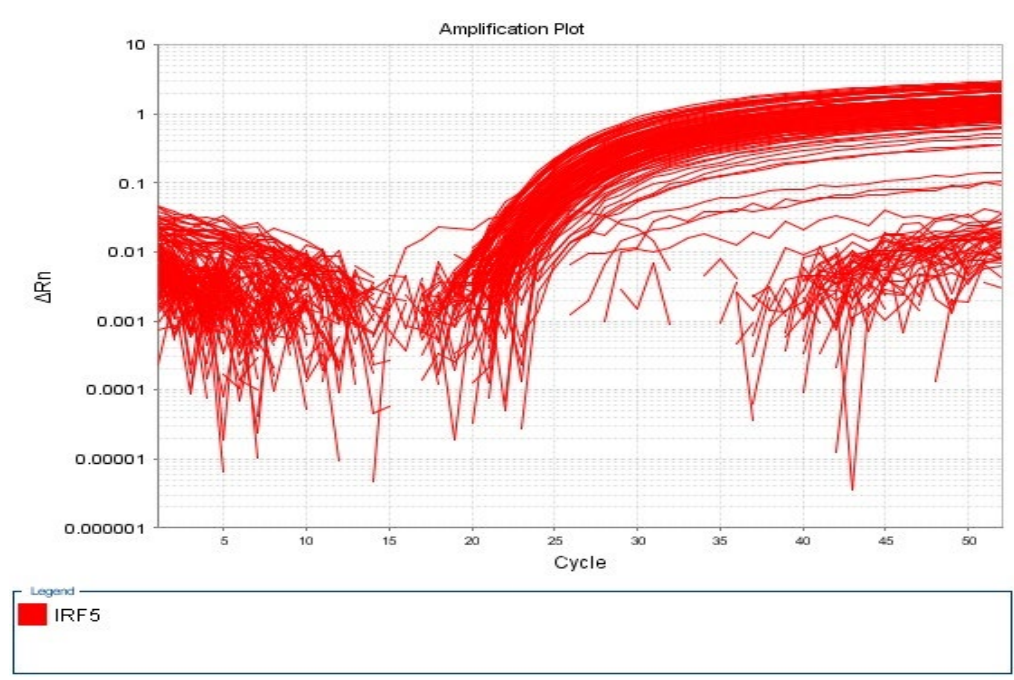

Figure1 : Amplification plot displaying normalized reporter $(\mathrm{Rn})$ dye (fluorescence) as a function of cycle

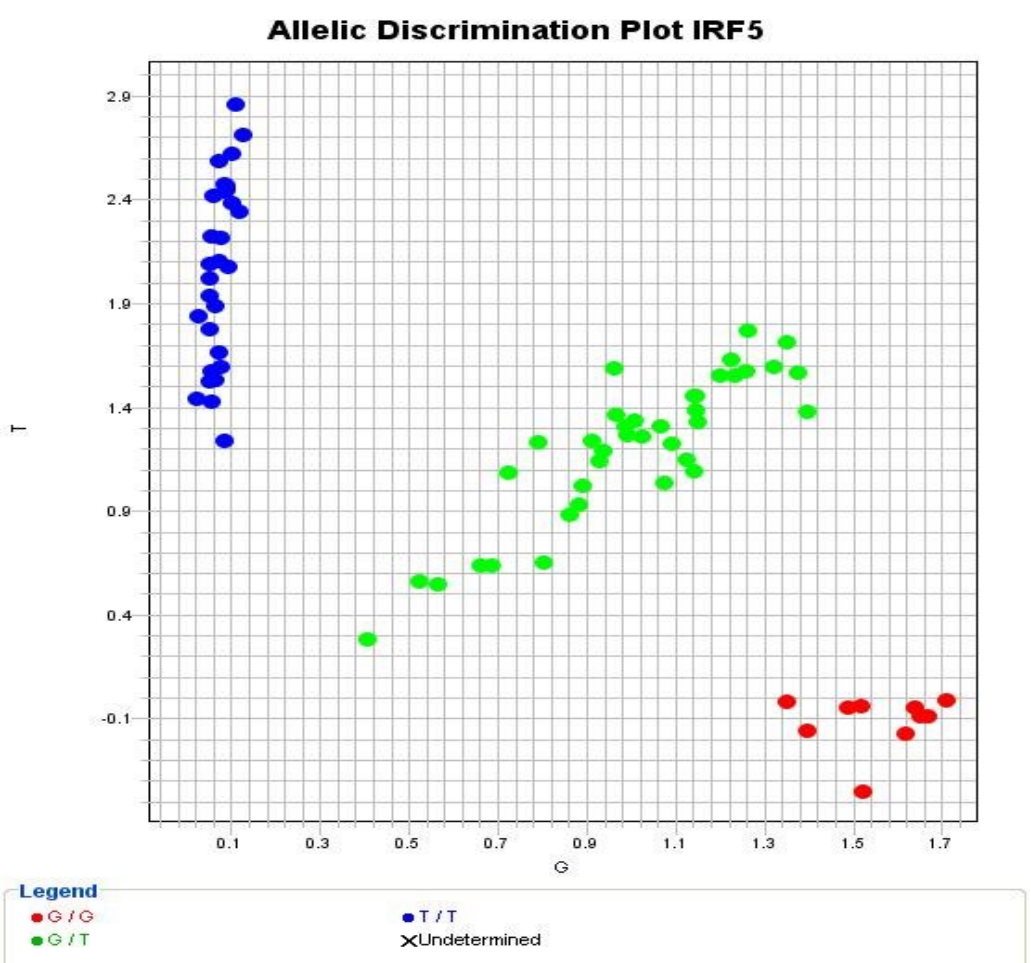

Figure2: Allelic discrimination plot showing GG, GT and TT genotypes of IRF5.

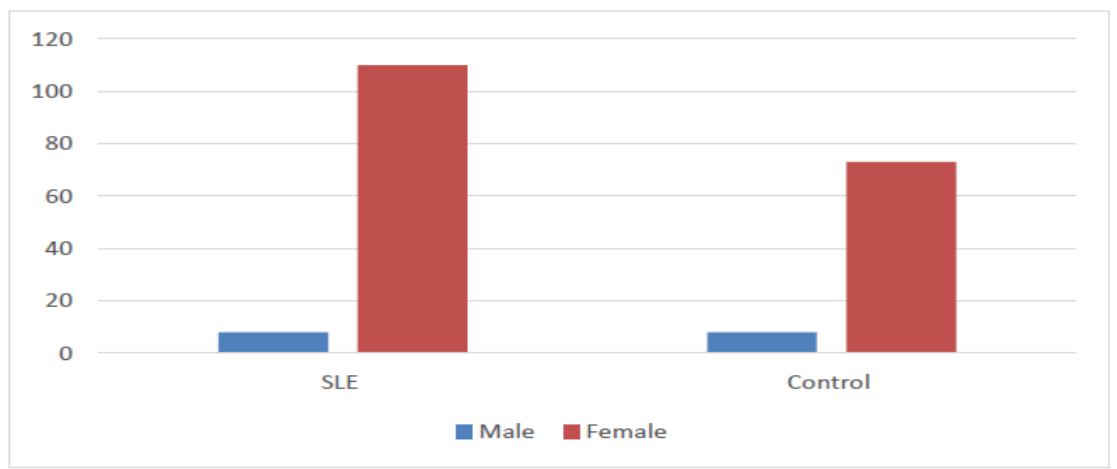

Figure 3: Sex distribution in the studied groups $(\mathrm{p}=0.2)$ 


\section{DISCUSSION}

SLE is a dangerous autoimmune disease, which exhibits variable clinical presentations. The definite pathogenesis of SLE is uncertain, and the etiology of SLE is multifactorial, including genetic, hormonal, and environmental factors together with drug intake and infections [15], also the cytokines have been proposed to be involved in the pathogenesis of SLE, as they are important components of regulation of immune response, that interfere in cellular and humoral responses [16]. Our study was performed to examine the link between the IRF5 gene polymorphism (rs2004640) with systemic lupus erythematosus \& lupus Nephritis and to predict SLE activity (assessed by SLEDAI score) in a sample of adult Egyptian population. In this study, there was a significant difference as regards genotype frequency of IRF5 rs2004640 between the SLE and controls, with high frequency of TT genotype among SLE patients and GG genotype among the control group. Allelic distribution showed that $\mathrm{T}$ allele was the abundant in SLE patients. These results are in accordance to Nordang et al. [17] who investigated the liability of variations in IRF5 rs2004640 to other autoimmune diseases as rheumatic illness and they found a new relationship between IRF5, rs2004640 and JIA, mostly in polyarthritis RF-negative individuals.

The main pathogenic mechanism linked with the increased levels of IFN- $\alpha$ in SLE patient is that Toll-like receptors (TLRs) and other receptors exist in the dendritic cells, upon detecting the specific ligand / antigens in immune complexes stimulate the release of IFN- $\alpha$ via the IRF5 transcription system which enhance transcription of many pro-inflammatory cytokines as IFN- $\alpha$, TNF- $\alpha$, IL12 and IL6 Devaraju et al [18].

In addition, Feng et al. [19] reported the principal approved evidence that IRF5 mRNA expression and alternative splicing showed significant up-regulation in SLE patients. Moreover, the dangerous haplotype is linked to increased IRF5 gene and protein expression in SLE patients. $T$ allele significantly showed the highest frequencies in SLE patients than controls in several populations especially, Western populations; in Argentina, Spain, Sweden, the USA and a Finland population, unlike, Asian populations including Japan and Korea $\mathrm{T}$ allele showed much lower frequency in SLE patients, in spite of this discrepancy in allelic frequencies, the relationship with SLE risk by the T allele showed the same tendency as all other previous studies. These data realistically proven the IRF5 gene implicated in the development of SLE [18]. The rs2004640 G/T polymorphism modifies the splicing process and enhances secretion of IFN- $\alpha$, which could magnify the autoimmune reactions through its pleiotropic impact on several cells in immune system [7]. On contrary to our results, Devaraju et al [18] revealed there was no significant association between rs2004640 gene variants and SLE in southern Indian populations. However Zervou et al [20] reported an enhanced liability for IRF5 gene rs2004640 variants in the Crete SLE population. Similarly, Sigurdsson et al (2008) [21] detected a significant relationship between IRF5 rs2004640 polymorphism and SLE in other populations such as Swedish, Finnish, and Icelandic ones. This discrepancy in results may be due to differences in sample sizes, research designs and genetic base of each population. 
Hammad et al [22] studied the genetic variants of the IRF5 gene and SLE risk in Egyptian pediatric cases and reported that the IRF5 (rs2004640) T allele and TT genotype are risky for SLE in children and the presence of the rs2004640 $\mathrm{T}$ allele elevates the danger of nephritis in Egyptian pediatric SLE cases in comparison to controls. On the other hand, genotype of IRF5 rs2004640 and its allelic distribution had no significant difference between lupus patients with and without nephritis, while, Qin et al [23] reported that the rs2004640 T allele was associated to risk of lupus nephritis development in comparison with controls.

\section{6 | CONCLUSION}

It was concluded that Interferon regulatory factor (5) gene polymorphism (rs2004640) might be a candidate risk factor for developing systemic lupus erythramatosus in a sample of adult Egyptian population, but not a risk factor for lupus nephritis or the disease activity.

- Consent for publication: Not applicable

- Availability of data and material: Not applicable

- Competing interests: There is no conflict of interest among authors.

- Funding: This research did not receive any specific grant from funding agencies in the public, commercial, or not-for-profit sectors

\section{- Authors' contributions:}

SME performed laboratory tests, also analyzed and interpreted the patient data and she is the corresponding author. HEK was a major contributor in writing the manuscript. ESZ analyzed and interpreted the results, RGM performed the immunological tests for participants of the study. ShE assisted in doing laboratory tests, all authors have read and approved the manuscript submission.

- Acknowledgements: We thank all cases and controls shared in our study, many thanks to Dr. Eman Elsayed Badr (Central Laboratory Manager) and members of central laboratory at menoufia faculty of medicine for facilitating real-time PCR step.

\section{References}

1- Chai, H.C., Chua, K.H., Lim, S.K. and Phipps, M.E. (2014). Insight into Gene Polymorphisms Involved in Toll-Like Receptor/Interferon Signalling Pathways for Systemic Lupus Erythematosus in South East Asia. Journal of Immunology Research; 2014: 1-9 http://dx.doi.org/10.1155/2014/529167

2- Moossavi, M., Shojaee, M., Mollashahi, A., Poodineh, J. and Moossavi, S. (2018): Effects of Interleukin Families Polymorphisms on Systemic Lupus Erythematosus: Focus on Interleukin-1. Gene Cell Tissue; 5:1-8. doi: 10.5812/gct.69365

3- Miettunen, P.M., Ortiz-Alvarez, O., Petty, R.E., Cimaz, R., Malleson, P., Cabral, D., et al. (2004). Gender and ethnic origin have no effect on longterm outcome of childhood-onset systemic lupus erythematosus. J Rheumatol; 31:1650-1654.

https://www.ncbi.nlm.nih.gov/pubmed/152907 $\underline{48}$

4- Tobón, G., Izquierdo, J. and Cañas, C. (2013): lymphocytes: development, tolerance, and their role in autoimmunity-focus on systemic lupus erythematosus. Autoimmune Dis.:1-17. 
https://www.ncbi.nlm.nih.gov/pubmed/241876

14

5- Liu, H., An, X., Yang, Y., Yang, L. and Yan, Li. (2013). Association of rs 10954213 Polymorphisms and Haplotype Diversity in Interferon Regulatory Factor 5 with Systemic Lupus Erythematosus: A Meta-analysis: J Huazhong Univ Sci Technol (Med Sci):33:1521.

https://www.ncbi.nlm.nih.gov/pubmed/233927 $\underline{01}$

6- Richez, C., Barnetche, T., Miceli-Richard, C., Blanco, P. and Moreau, J.F. (2010): Role for interferon regulatory factors in autoimmunity. Joint Bone Spine: 77: 525-531. https://www.ncbi.nlm.nih.gov/pubmed/208637 $\underline{36}$

7- Jensen, M.A. and Niewold, T.B. (2015): Interferon regulatory factors: Critical mediators of human lupus. Transl Res; 165: 283-295. https://www.ncbi.nlm.nih.gov/pubmed/254452 $\underline{06}$

8- Graham, R. R., Kozyrev, S. V., Baechler, E. C., Reddy, M. V. P. L., Plenge, R. M., Bauer, J. W. Alarcón-Riquelme, M. E. (2006). A common haplotype of interferon regulatory factor 5 (IRF5) regulates splicing and expression and is associated with increased risk of systemic lupus erythematosus. Nature Genetics, 38(5), 550-555. https://doi.org/10.1038/ng1782

9- Weening, J.J., D’Agati, V.D., Schwartz, M.M. (2004). The classification of glomerulonephritis in systemic lupus erythematousus revisited. Kidney Int; 65: 52130. https://www.ncbi.nlm.nih.gov/pubmed/147473 $\underline{70}$

10- Hochberg, M.C. (1997). Updating the American College of Rheumatology revised criteria for the classification of systemic lupus erythematosus. Arthritis Rheum; 40: 1725. https://www.ncbi.nlm.nih.gov/pubmed/932403 $\underline{2}$

11- Bombardier, C., Gladman, D.D., Urowitz, M.B., Caron, D., Chang, C. (1992). Derivation of the SLEDAI. A disease activity index for lupus patients. The committee on prognosis studies in SLE. Arthritis Rheum; 35: 630-40.

https://www.ncbi.nlm.nih.gov/pubmed/159952 $\underline{0}$

12- Levey, A.S., Coresh, J., Greene, T., Stevens, L.A., Zhang, Y., Hendriksen, S., Kusek, J.W., Van Lente, F., 2006. Using standardized serum creatinine values in the modification of diet in renal disease study equation for estimating glomerular filtration rate. Ann. Intern. Med. 145, 247-254. https://doi.org/10.7326/0003-4819-145-4200608150-00004.

13- Al-sheikh N, El-Hefnway S, El-Shetahy A (2018): Cholesterol 7- alpha hydroxylase gene (CYP7A1) promoter polymorphism rs3808607 as a risk factor for pulmonary tuberculosis in Egypt, Meta Gene. 16: 66-71

14- Saleh, A., Alhanafy, A., Elbahr, O. and ElHefnawy. S. (2020): Chitinase 3-like 1 gene (T/C) polymorphism and serum YKL-40 levels in patients with hepatocellular carcinoma, Meta Gene, $24: 100686$ 
15- Tiffin, N., Adeyemo, A. and Okpechi, I. (2013). A diverse array of genetic factors contribute to the pathogenesis of systemic lupus erythematosus. Orphanet J Rare Dis.; 8:2. https://www.ncbi.nlm.nih.gov/pubmed/232897 17

16- Mellor-Pita, S., Citores, M.J., Castejon, R., Tutor-Ureta, P., Yebra-Bango, M., Andreu, J.L., Vargas, J.A. (2006). Decrease of regulatory $\mathrm{T}$ cells in patients with systemic lupus erythematosus. Ann Rheum Dis. 2; 65:553-554.

https://www.ncbi.nlm.nih.gov/pmc/articles/PM $\underline{\mathrm{C} 1798083}$

17- Nordang, G.B., Viken, M., Amundsen, S., Sanchez, B., Flatø, O.T., Førre, J., Martin, T.K., Kvien, B.A. (2012): Interferon regulatory factor 5 gene polymorphism confers risk to several rheumatic diseases and correlates with expression of alternative thymic transcripts. Rheumatology. ;51:619-626. https://www.ncbi.nlm.nih.gov/pubmed/221797 $\underline{39}$

18- Devaraju, P., Mehra, S., Gulati, R., Antony, P. and Vikramraj, J. (2018): The IRF5 rs2004640 (G/T) polymorphism is not a genetic risk factor for systemic lupus erythematosus in population from south India. Indian J Med Res 147:560-5661.

https://www.ncbi.nlm.nih.gov/pubmed/301684

19- Feng D, Stone RC, Eloranta ML, et al. Genetic variants and disease-associated factors contribute to enhanced interferon regulatory factor 5 expression in blood cells of patients with systemic lupus erythematosus. Arthritis and Rheumatism. 2010 Feb;62(2):562-573.

DOI: $10.1002 / \operatorname{art} .27223$

20- Zervou, M., Dorschner, J., GhodkePuranik, Y., Boumpas, D., Niewold, T .and Goulielmos , G. (2017): Association of IRF5 polymorphismswith increased risk for systemic lupus erythematosus in population of Crete, a southern-eastern European Greek island. Gene 610

9-14.

http://dx.doi.org/10.1016/j.gene.2017.02.003

21- Sigurdsson S, Nordmark G, Göring HH, et al. Polymorphisms in the tyrosine kinase 2 and interferon regulatory factor 5 genes are associated with systemic lupus erythematosus. Am J Hum Genet. 2005;76(3):528-537. doi:10.1086/428480

22- Hammad, A., Mossad, Y., Nasef, N. and Eid, R. (2017): Interferon regulatory factor 5 gene polymorphism in Egyptian children with systemic lupus erythematosus ; 26 :871-880. https://www.ncbi.nlm.nih.gov/pubmed/280590 $\underline{21}$

23- Qin, L., LV, J., Zhou, X ., Hou , P., Yang , H. and Zhang, H. (2010): Association of IRF5 gene polymorphisms and lupus nephritis in a Chinese population. Nephrology; 15: 710 713.

https://www.ncbi.nlm.nih.gov/pubmed/210401 $\underline{66}$ 